\title{
Influence of Organo-Montmorillonite on Electrical Tree Parameters in Epoxy Resin Under Ac Ramp Voltage
}

\author{
Mohd Hafiez Izzwan Saada, Mohd Hafizi Ahmada, Yanuar Z. Ariefa ${ }^{*}$, Hussein Ahmada, Mohamed Afendi Mohamed Piaha \\ aInstitute of High Voltage \& High Current (IVAT), Faculty of Electrical Engineering, Universiti Teknologi Malaysia, 81310 UTM Johor Bahru, \\ Malaysia \\ *Corresponding author: yzarief@fke.utm.my
}

\section{Article history}

Received :15 February 2013

Received in revised form :

10 June 2013

Accepted :16 July 2013

Graphical abstract

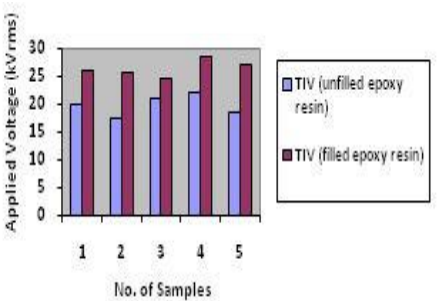

Tree inception voltage of unfilled epoxy resin and filled epoxy resin schematic diagram of electrical tree test rig

\begin{abstract}
This paper discusses the effects of nanofiller on electrical treeing growth in polymer nanocomposites. The polymer nanocomposite consists of epoxy resin as the base polymer and organo-montmorillonite as the nanofiller. The influence of this nanofiller on the electrical treeing breakdown resistance was investigated experimentally. The quantity of organo-montmorillonite were added in epoxy resin by ultrasonication method based on weight percentage (wt\%). The weight percentages used in this experiment were $0 \mathrm{wt} \%$ and $1 \mathrm{wt} \%$, respectively. All the samples were produced in the form of leaf-like specimens which were categorized into two parts: unfilled sample $(0 \mathrm{wt} \%)$ and filled sample $(1 \mathrm{wt} \%)$. Point-to-plane samples were subjected to $0.5 \mathrm{kVrms} / \mathrm{s}$ HVAC ramp voltage. The data of tree inception voltage and tree breakdown voltage were collected and comparative results were made and presented. The morphological analysis of epoxy nanocomposites were investigated using field emission scanning electron microscopy (FESEM). Electrical tree parameters analysis has shown that the existence of organo-montmorillonite in epoxy resin could exhibit significant improvement of tree characteristics of epoxy resin nanocomposites as the nanofiller contributed to the increase of tree inception voltage and tree breakdown voltage.
\end{abstract}

Keywords: Electrical tree; epoxy resin; organo-montmorillonite; nanofiller; FESEM

\begin{abstract}
Abstrak
Jurnal ini membincangkan tentang kesan pengisi bersaiz nano ke atas fenomena pepohon elektrik di dalam polimer nanokomposit. Polimer nanokomposit ini terdiri daripada resin epoksi sebagai polimer asas dan organo-montmorilonite (OMMT) sebagai pengisi bersaiz nano. Pengaruh pengisi nano ini terhadap rintangan pecah tebat pepohon elektrik diuji melalui eksperimen. Kuantiti OMMT ditambah dalam resin epoksi dengan kaedah ultrasonikasi berdasarkan peratusan berat (wt \%) yang mana peratusan berat yang digunakan dalam eksperimen ini adalah $0 \mathrm{wt} \%$ dan $1 \mathrm{wt} \%$. Kesemua sampel yang dihasilkan dalam bentuk spesimen "leaf-like" dikategorikan kepada dua bahagian: sampel tidak berisi (0 wt\%) dan sampel berisi (1 wt\%). Sampel titik-ke-satah diuji menggunakan voltan tanjakan $0.5 \mathrm{kVrms} / \mathrm{s}$ HVAC . Data voltan permulaan pepohon elektrik dan voltan pecah tebat pepohon elektrik dikumpulkan dan perbandingan keputusan dibuat dan dibentangkan. Analisis morfologi epoksi nanokomposit telah disiasat menggunakan pelepasan bidang mikroskop elektron imbasan (FESEM). Analisis parameter pepohon elektrik telah menunjukkan bahawa kewujudan OMMT dalam resin epoksi menunjukkan peningkatan ciri-ciri pepohon elektrik dalam resin epoksi nanokomposit dimana pengisi bersaiz nano menyumbang kepada peningkatan permulaan pepohon elektrik dan voltan pecah tebat pepohon elektrik.
\end{abstract}

Kata kunci: Pepohon elektrik; resin epoksi; organo-montmorillonite, pengisi bersaiz nano; FESEM

\subsection{INTRODUCTION}

Up-to-date, numerous researches have been performed to study electrical properties and characteristics of electrical treeing in polymer nanocomposites when subjected to high electrical

Electrical treeing is one of the main factors for the long term degradation of polymeric insulation under continuously alternating current [3]. Electrical treeing is defined as a process of stresses. Most researchers focus on thermosetting and thermoplastic polymer such as silicone rubber, epoxy resin, polyethylene polyvinyl etc. The use of nanocomposites as an insulating medium are quite common because of its excellent thermal, chemical, mechanical and electrical properties [1]-[2] partial discharge electrical breakdown in a solid dielectric at very high electric field regions [4]. There are various types of electrical 
trees such as bushed, branched, monkey-puzzle trees and bushbranched trees.

From previous researches, Nagao et al [5] and Kurnianto et al. [6] presented a study about the effects of silica filler on treeing phenomenon in epoxy resin. They found that filler particles would create an obstruction to the tree propagation in the specimen. Later in 2008, Alapati et al. [7] carried out experiments to find the effects of silica nanofiller on tree initiation time. From the obtained results, they found that addition of small amount $(1 \%$ by weight) of nano silica particles in epoxy resin can improve treeing resistance. A similar study was also conducted by Raetzke et al. [8]. They pointed out that tree initiation time was prolonged by the addition of nanoclay of $5 \mathrm{wt} \%$ to neat epoxy/clay composite material. Investigations of alumina nanofiller and silica nanofiler have been done by Huicheng et al. [9] in 2009. They studied the effects of nanofiller in filled epoxy resin in term of relative permittivity and loss tangent. They found out that both parameters in filled epoxy-alumina larger than filled epoxy-silica. Ding et al. [10] discussed about the effect of nano-sized filler on electrical treeing subjected to AC voltage. From their study, they found that the addition of zinc oxide particles into epoxy resin has improved the resistance to electrical tree growth and increased the time to breakdown.

In 2009, Guastavino et al. [11] have studied the growth of electrical treeing inside different Ethylene-vinyl acetate (EVA) nanocomposites containing Boehmite (an aluminum oxide hydroxide) and Montmorillonite (a phyllosilicate clay mineral) nanoparticles. Experimental results have shown that the growth of the electrical treeing inside the original polymer can generate a barrier to the growth of the discharge channels. Besides, Jinmei et al. [12] investigated the effects of electrical tree and partial discharge properties on original polyethylene and polyethylene/montmorillonite nanocomposites. The authors found that, compared with original polyethylene, polyethylene/montmorillonite demonstrated better electrical treeing and partial discharge resistance.

The study of electrical treeing in epoxy/organomontmorillonite insulating material is lacking. Thus in this paper, a study has been performed to investigate the influence of organomontmorillonite (OMMT) on the electrical tree initiation and breakdown in epoxy resin nanocomposites material via leaf-like specimen.

\subsection{MATERIALS AND METHODS}

EPIKOTE 1007, epoxy resin was employed as insulating material in this study. The epoxy resin was supplied by Momentive. This resin is produced from Bisphenol A and Epichlorohydrin. For curing agent, Momentive's EPIKURE 200-N-60 was employed. To harden the resin, curing agent was mixed in 10:7 resin/hardener ratios. The OMMT used in this study is purchased from Nanocor, Inc. USA. It is Nanomer 1.30P. The OMMT is montmorillonite clay modified with octadecylamine to reduce MMT's hydrophilic nature. This OMMT contains montmorillonite (70 wt $\%$ ) intercalated by octadecylamine $(30 \mathrm{wt} \%)$. The mean dry particle size of the OMMT is in the range of 16-22 microns.

For the nanocomposites sample preparation, firstly, $1 \mathrm{wt} \%$ of nanofiller was added to the EPIKOTE 1007 resin (100 wt\%). This compound was mixed using Fisher FB-705B ultrasonic dismembrator. This sonication process were done for 20 minutes to get homogeneously dispersed nanoparticles in resin matrix. After that, this compound was mixed with the EPIKURE 200-N60 curing agent $(6 \mathrm{wt} \%)$ using magnetic stirrer under speed of 125 $\mathrm{rpm}$ at $40^{\circ} \mathrm{C}$ for about 4 minutes. After this process, the nanocomposites compound was degassed at pressure of $29 \mathrm{inHg}$ under room temperature for about 10 minutes to remove the bubbles. After degasification process, the final compound was pour to the slide glass to cover the point-plane gap in order to form a specimen which is called leaf-like specimen. This type of specimen were fabricated because it helps to give sufficient resolution for microscopic observation of tree initiation, propagation until breakdown. Hence, $1 \mathrm{~mm}$ thick specimens were fabricated in this study. The needle electrode is made from tungsten wire with $0.25 \mathrm{~mm}$ diameter. The needle tip were sharpened using Sodium Hydroxide $(\mathrm{NaOH})$. This process is called electrolytic etching.

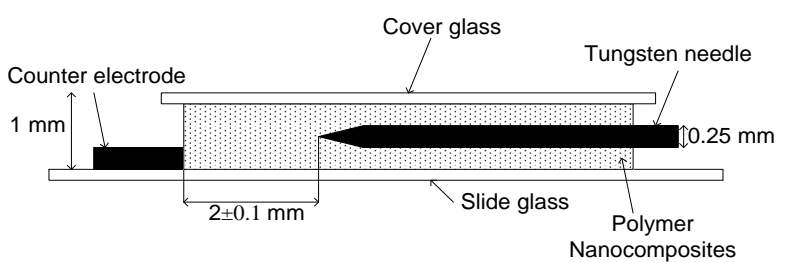

Figure 1 Configuration of leaf-like specimen [13]

The needles that meet the required specifications were fixed on the slide glass to get a needle-foil (point-plane) gap of $2 \mathrm{~mm}$. The gap distance tolerance is about $\pm 0.1 \mathrm{~mm}$. After that, the electrode gap was covered with nanocomposites material as mentioned above. The finished leaf-like specimens were left at room temperature for about 3 hours for curing purpose. The samples were categorized into unfilled epoxy resin (neat epoxy resin) and filled epoxy resin (epoxy resin with $1 \mathrm{wt} \%$ of OMMT). The leaf-like specimen configuration is shown in Figure 1.

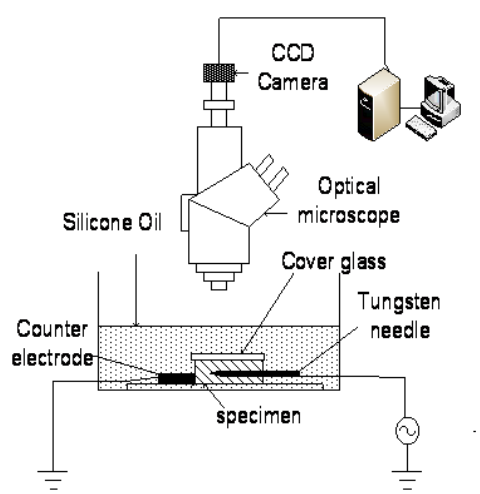

Figure 2 Schematic diagram of electrical tree test rig [14]

The cured leaf-like specimens were subjected to $0.5 \mathrm{kV}_{\mathrm{rms} / \mathrm{s}} \mathrm{AC}$ ramp voltage at $50 \mathrm{~Hz}$ until breakdown. The tree inception voltage was measured when the tree length observed by CCD camera roughly exceeded $10 \mu \mathrm{m}$, whereas, tree breakdown voltage was measured when the tree has bridged the electrode gap. All tests were carried out under ambient temperature. The tree initiation, propagation and breakdown were recorded through the Olympus DP26 camera which mounted on the SZX16 Olympus research stereomicroscope. The schematic diagram of electrical tree test rig is shown in Figure 2. 


\subsection{RESULTS AND DISCUSSION}

For each test, 5 samples were tested and tree inception voltage (TIV) and tree breakdown voltage (TBV) were recorded and measured. The obtained results of the tree inception voltage (TIV) and tree breakdown voltage (TBV) of unfilled epoxy resin and filled epoxy resin are shown in Figure 3 and Figure 4 respectively.

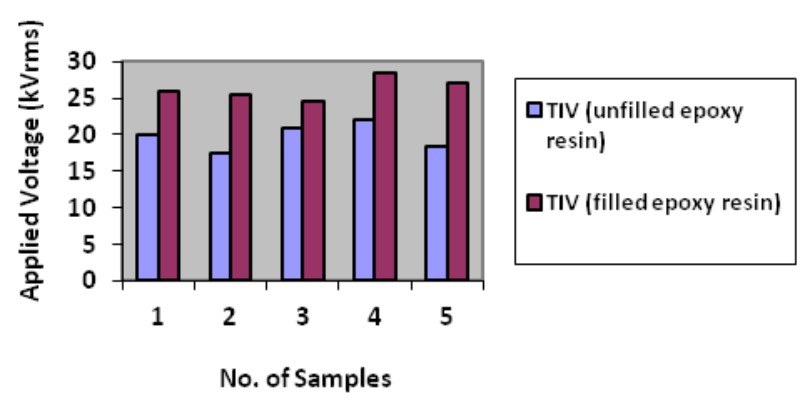

Figure 3 Tree inception voltage of unfilled epoxy resin and filled epoxy resin schematic diagram of electrical tree test rig

Figure 3 illustrates the comparison of TIV between unfilled epoxy resin and filled epoxy resin. It can be seen that the TIV of filled epoxy is higher than unfilled epoxy resin. Thus, it can be clarified that the filled epoxy resin has taken longer time to initiate electrical trees compared with unfilled epoxy resin which need shorter time to initiate the tree. Higher energy is required to break the chemical bonds of resin and hence form a void which is required for partial discharge activities. These activities will eventually help to create the treeing and in nanocomposites samples, the addition of $1 \mathrm{wt} \%$ of nanofiller in resin matrix helped to delay the initiation of electrical. Thus, higher voltage is required to initiate the treeing.

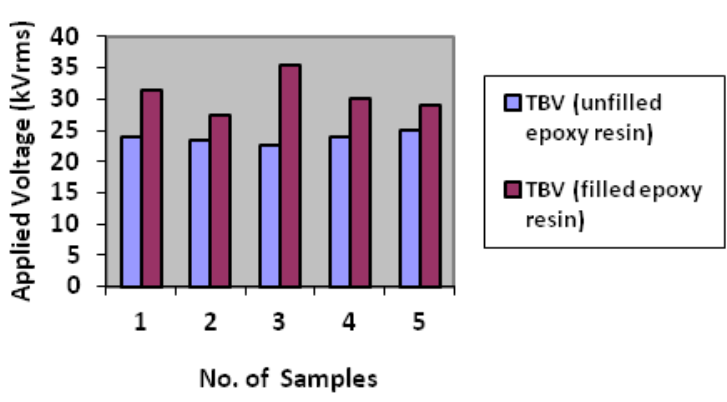

Figure 4 Tree Tree breakdown voltage of unfilled epoxy resin and filled epoxy resin

Table 1 Electrical tree progression in unfilled epoxy resin and filled epoxy resin

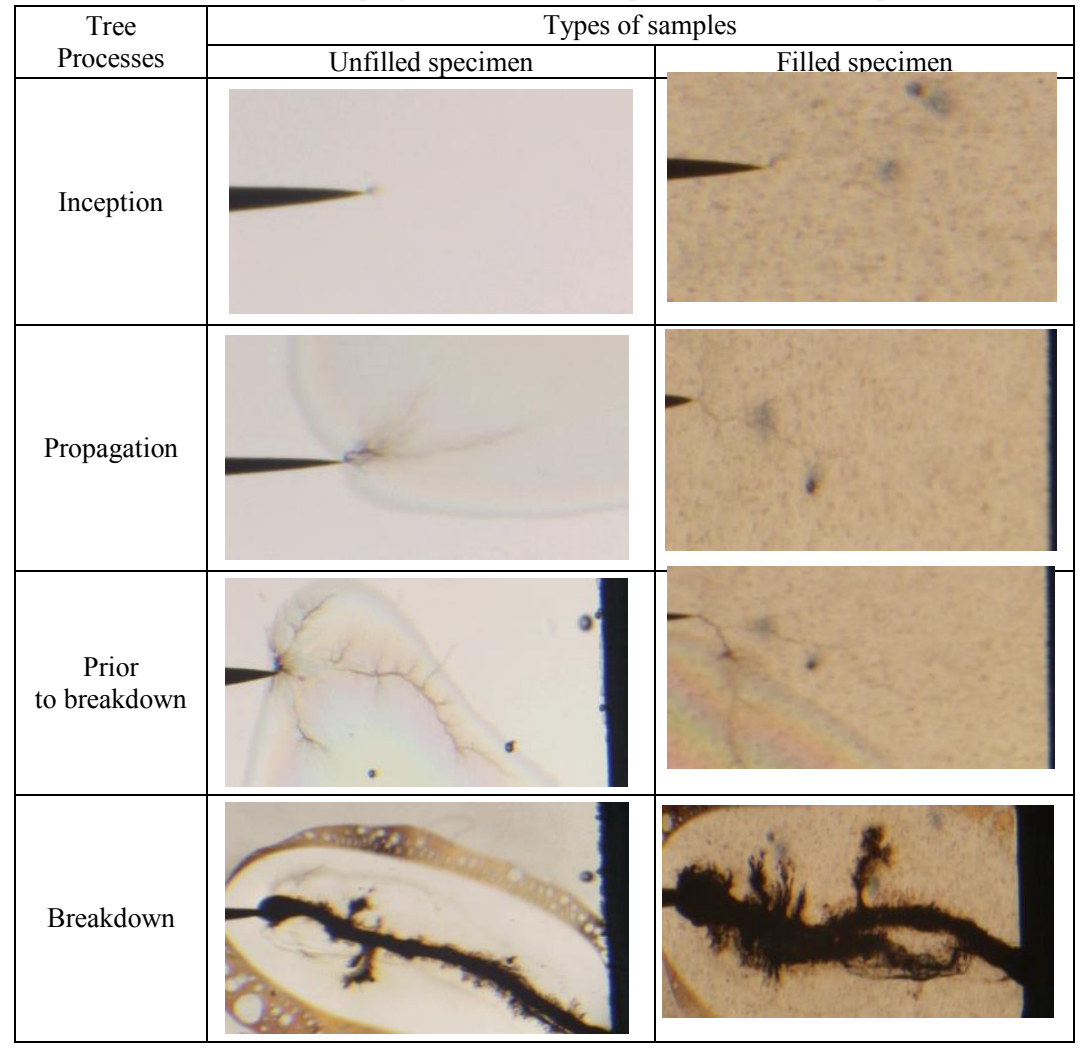


Figure 4 illustrates the TBV of both unfilled and filled epoxy resin. It obviously shows that trees in filled specimens have taken longer time to breakdown because higher breakdown voltage is required for trees to bridge the electrode gaps. Meanwhile, unfilled epoxy resin samples required lower voltage and shorter time to bridge the electrode gaps and cause breakdown. The addition of nanoparticles in the resin matrix helped to improve the dielectric strength of the nanocomposites. Besides, the nanofiller provide more trap levels for epoxy resin matrix, which traps the free charge carrier during charge carrier transfer. Moreover, electrical tree channels are forced to collide with the nanofiller surfaces. This kind of collision helps to slow down the tree growth and prolong the time to breakdown which would increase the tree breakdown voltage. The tree images which were recorded during the $\mathrm{AC}$ ramp voltage test are depicted in Table 1 .

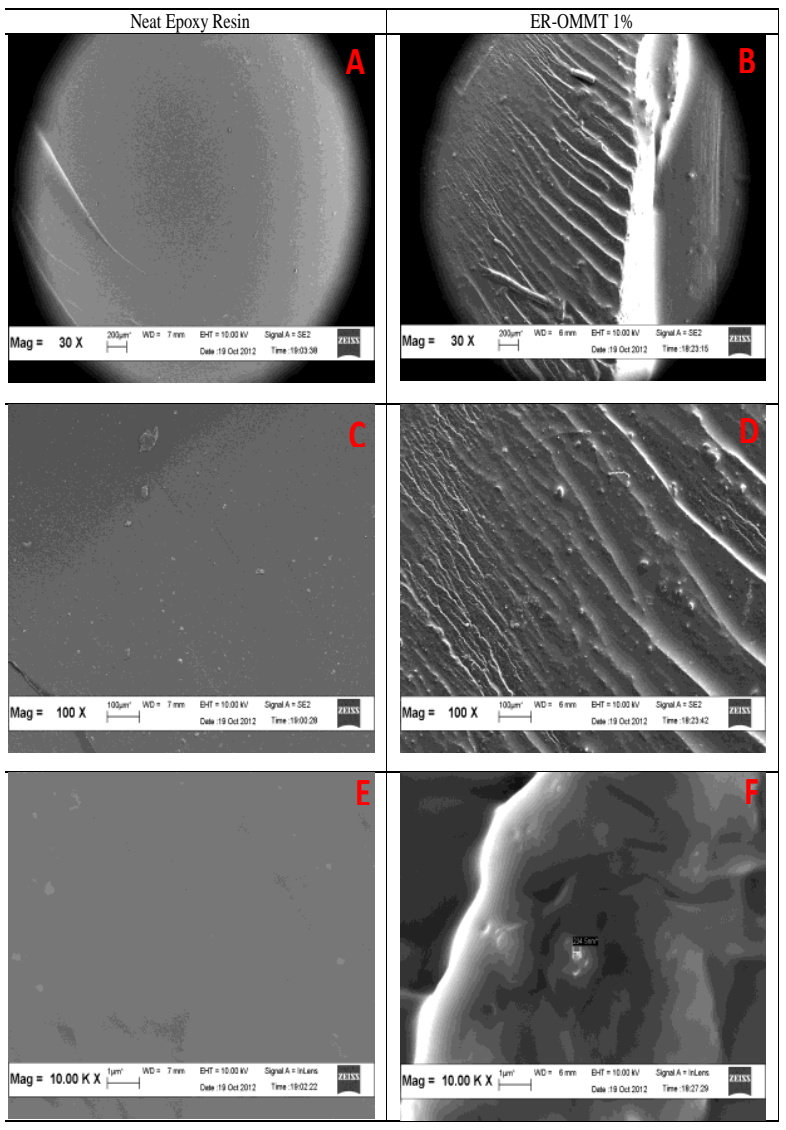

Figure 5 FESEM spectra of neat epoxy resin (A, C, E) and ER-OMMT $1 \%(\mathrm{~B}, \mathrm{D}, \mathrm{F})$ with different magnification

It is very crucial to analyze the behavior of tree propagation inside the sample. The tree progressions were divided into four stages; inception, propagation, prior to breakdown and breakdown. From the tree progression in Table 1 , propagation of treeing in unfilled specimens can be seen to be vulnerable and more translucent compared with filled specimens. Prior to breakdown, trees propagated in both samples in the form of branch-type trees. By referring to breakdown stage, carbon tracks across electrodes in filled specimen are more densely packed compared to unfilled specimen due to higher breakdown voltage required for breakdown to occur. This phenomenon indicates that the existence of nanoparticles in polymer matrix would increase the dielectric strength of sample and enhance chemical bonds of epoxy resin. As results, average voltages of TIV for unfilled and filled specimens are calculated and equal to $19.8 \mathrm{kV}$ and 26.3 $\mathrm{kV}$ respectively. The average values of TBV are calculated as well and equal to $24.3 \mathrm{kV}$ and $30.7 \mathrm{kV}$ for unfilled and filled epoxy resin respectively. Based on the observation, the addition of $1 \mathrm{wt} \%$ of OMMT in epoxy resin has reinforced the polymeric structures of epoxy resin nanocomposites against the electrical treeing initiation, propagation until breakdown.

Despite the two vital treeing parameter discussed previously, morphological analysis which is the dispersion of nanoclay OMMT into the polymer matrix epoxy resin by field emission scanning electron microscopy (FESEM) was investigated. The fractured surface of the specimens were sputter coated with platinum prior to FESEM investigation. Figure 5 shows the images of the fractured surface of neat epoxy resin and ER-OMMT (1\%) designated by alphabet A, C, E and $\mathrm{B}, \mathrm{D}, \mathrm{F}$ respectively. The first one was neat epoxy resin and a smooth fractured surface could be observed through Figure $5 \mathrm{~A}$, $\mathrm{C}$ and $\mathrm{E}$. This indicates that neat epoxy resin is brittle structured which accounted for its poor polymer matrix strength compared to epoxy resin nanocomposites. Refering to Figure 5 B, D and F, it can be shown that the OMMT nanofiller succesfully dispersed uniformly in epoxy resin polymer matrices. Figure $5 \mathrm{~F}$ shows the existence of nanofiller in nanosize and have uniform distance between particles. It was observed that the nanofiller OMMT was exfoliated in epoxy resin polymer matrix compared with neat epoxy resin. This affected the electrical tree characteristics overall.

\subsection{CONCLUSION}

Two main electrical tree parameters, tree inception voltage and tree breakdown voltage of unfilled epoxy resin and filled epoxy resin samples were successfully investigated. The effects of nanofiller on the tree inception voltage and tree breakdown voltage were explained. The growth stages of electrical treeing in filled and unfilled epoxy resin were explained thoroughly. However, further research should be done for epoxy resin with several weight percentages (wt\%) of OMMT nanoclay to investigate the performance capabilities of epoxy resin-OMMT polymer nanocomposites as an inhibitor for electrical treeing. This preliminary work is expected to open more new significant findings on the important of the nanofiller as an electrical tree retardant material particularly in high voltage applications.

\section{Acknowledgement}

The author wishes to thank Universiti Teknologi Malaysia and Ministry of High Education (MOHE) for financial support. This research project was carried out under vote 05J07, 03J15 and 4F022. The authors would like to thank Mr. Abdul Azim Abdul Jamil for his help during this study was performed. Last but not least, we would like to thank Dr. Nouruddeen Bashir for his valuable advice and support.

\section{References}

[1] M. Danikas and T. Tanaka. 2009. Nanocomposites-A Review Of Electrical Treeing and Breakdown. IEEE Electrical Insulation Magazine. 25(4): 19-25.

[2] A. A. A. Jamil, M. Kamarol, M. Mariatti, N. Bashir, M. H. Ahmad, Y. Z. Arief, and N. A. Muhammad. 2012. Organo-Montmorillonite as an Electrical Treeing Retardant for Polymeric Insulating Materials. In 
2012 IEEE International Conference on Condition Monitoring and Diagnosis 23-27 September 2012, Bali, Indonesia. 237-240.

[3] M. Ahmad, H. Ahmad, N. Bashir, Y. Z. Arief, Z. Abdul-Malek, R. Kurnianto, and F. Yusof. 2012. A New Statistical Approach for Analysis of Tree Inception Voltage of Silicone Rubber and Epoxy Resin under AC Ramp Voltage. International Journal on Electrical Engineering and Informatics. 4(1):27-39.

[4] L. A. Dissado and J. C. Fothergill. 1992. Electrical Degradation and Breakdown in Polymers. 2nd ed. Peter Peregrinus Ltd, United Kingdom. 117-143.

[5] M. Nagao, K. Oda, K. Nishioka, Y. Muramoto, and N. Hozumi. 2001. Effect of Filler on Treeing Phenomenon in Epoxy Resin under AC Voltage. Proceedings of 2001 International Symposium on Electrical Insulating Materials, 2001. (ISEIM 2001). 611-614.

[6] R. Kurnianto, Y. Murakami, N. Hozumi, and M. Nagao, 2007. Characterization of Tree Growth in Filled Epoxy Resin: The Effect of Filler and Moisture Contents. IEEE Transactions on Dielectrics and Electrical Insulation. 14(2): 427-435.

[7] S. Alapati and M. Thomas. 2008. Electrical Treeing in Polymer Nanocomposites. In Fifteenth National Power Systems Conference. 351-355.

[8] S. Raetzke, Y. Ohki, T. Imai, T. Tanaka, and J. Kindersberger. 2009 Tree Initiation Characteristics of Epoxy Resin and Epoxy/Clay Nanocomoposite. IEEE Transactions on Dielectrics and Electrical Insulation. 16(5): 1473-1480.
[9] H. Shi, N. Gao, H. Jin, G. Zhang, Z. Peng, and P. Equipment, 2009. Investigation of the Effects of Nano-Filler on Dielectric Properties of Epoxy Based Composites. In 2009 IEEE 9th International Conference on the Properties and Applications of Dielectric Materials. 804-807.

[10] H. Ding and B. Varlow. 2004. Effect of Nano-fillers on Electrical Treeing in Epoxy Resin Subjected to AC Voltage. In Annual Report Conference on Electrical Insulation and Dielectric Phenomena CEIDP'04. 332-335.

[11] F. Guastavino, A. Dardano, G. C. Montanari, L. Testa, and F. Bellucci. 2009. Electrical Treeing in EVA-Boehmite and EVA-Montmorillonite Nanocomposites. In 2009 IEEE Electrical Insulation Conference. 382 386.

[12] Z. Jinmei and G. Junguo. 2008. Studies on Electrical Tree And Partial Discharge Properties of PE/MMT Nanocomposites. In Proceedings of 2008 International Symposium on Electrical Insulating Materials, September 7-11, 2008, Yokkaichi, Mie, Japan. 311-314.

[13] M. H. Ahmad, H. Ahmad, N. Bashir, A. A. A. Jamil, M. A. M. Piah, Z. A. Malek, and S. J. Dodd. 2012. Electrical Treeing In Silicone Rubber/organo-montmorillonite. In 2012 Annual Report Conference on Electrical Insulation and Dielectric Phenomena. 898-901.

[14] M. H. Ahmad, H. Ahmad, N. Bashir, Z. A. Malek, Y. Z. Arief, and R. Kurnianto. 2011. Statistical Study on Tree Inception Voltage of Silicone Rubber and Epoxy Resin. In Proceedings of the 2011 International Conference on Electrical Engineering and Informatics. $1-6$. 